\title{
PERANG ARMAGEDON
}

\author{
Dr. Lanny Laras Tumbel \\ Sekolah Tinggi Teologi Injili Indonesia Surabaya \\ E-mail: lannylaras@sttii-surabaya.ac.id
}

\begin{abstract}
The Armageddon will be the site of gathering of armies for a battle during end times, variously interpreted as either or symbolic location. The term is also used a generic sense to refer to end of the world scenario. According to the Bible, Jesus will return to earth and defeat the Antichrist, the False prophet and Satan the Devil in the Battle of Armageddon. Then Satan will be put into the "bottomless pit" or abyss for 1,000 years, knows as the Millennium.
\end{abstract}

Keywords: Armageddon, prophet, Millennium

\section{PENDAHULUAN}

Dalam kurun waktu beberapa dekade saja telah terjadi perubahan yang luar biasa terhadap keadaan dunia ini. Dalam berbagai aspek kehidupan terjadi pergerakan nilai-nilai dan perubahanperubahan fisik yang sedemikian nampak nyata berbeda. Perubahan tersebut ada yang bersifat positif seperti loncatan-loncatan ilmu pengetahuan walaupun banyak dampaknya bersifat negative, dan ada pula yang tidak dapat disebutkan bersifat positif karena kecenderungannya bersifat negative dan tidak membangun.Keadaan dunia yang semakin memprihatinkan seperti meningkatnya peperangan di dunia ini, keadaan alam yang semakin menurun contohnya: pemanasan global dan dampaknya pada keberlangsungan hidup di dunia ini, gempa bumi yang semakin hari semakin sering dan meluas ke seluruh dunia. Keadaan-keadaan ini akan mencapai puncaknya di akhir zaman nanti ketika ketegangan dunia semakin menjadi dan kuasa kegelapan bekerja luar biasa sampai pada suatu puncak peperangan akhir di dunia ini, dimana manusia akan berperang melawan Allah Yang Mahakuasa.

Keprihatinan dunia juga akan mencapai puncak pada penghancuran-penghancuran yang akan terjadi atas manusia, lingkungan dan alam semesta.

Di akhir zaman nanti akan terjadi suatu peperangan besar di dunia ini yang di dalam surat Wahyu 16:16 disebut sebagai perang Harmagedon.

Kata Harmagedon dijelaskan dalam wahyu 16:16 sebagai bahasa Ibrani dari peperangan besar itu. Istilah "harmagedon" hanya dipakai satu kali di dalam Alkitab, berasal dari kata Har Magedon. Istilah ini dalam bahasa Ibrani berarti Gunung
Megido, dan selain di dalam ayat ini istilah Gunung Megido juga tidak dipakai di mana pun di dalam Alkitab. Istilah Megido sendiri dipakai dua belas kali dalam Perjanjian Lama, terutama dalam konteks perang (Hakim-hakim 5:19; 2 Raja-raja 9:27; 23:29; dan 2 Tawarikh 35:22). Rupanya lokasi gunung Megido sudah tidak diketahui lagi, tetapi tempatnya tidak jauh dari Megido sendiri di sebelah utara Gunung Karmel, dan di sana ada lembah yang luas dan strategis untuk perang. ${ }^{1}$ Megido sendiri berarti "melaporkan sebuah pesan", adalah sebuah kota di tepi selatan Dataran Esdraelom (Yizreel) di Timur Laut Gunung Karmel (Yos. 12:21; 17:11; Za. $12: 11)^{2}$

Harmagedon adalah tempat pertemuan dalam adegan apokaliptis Hari Besar Allah Yang Mahakuasa (Wahyu 16:16; tidak ditemukan di tempat lain). Kalau itu hanyalah nama simbolis saja, maka ketepatannya secara geografis tidak begitu penting. Penafsiran dahulu yang diketahui dan masih ada, hanyalah dalama bahasa Aran dan manfsirkannya "permukaan datar" (Arab 'Imwd' 'lwty' = tanah datar?) (Hippolytus, red. Bonwetsch). Dari empat macam tafsiran modern tentang Harmagedon yakni 'gunung Megido', 'kota Megido' 'gunung pertemuan' (C.C. Torrey), dan 'bukit yang penuh buah', kebanyakan sarjana lebih cenderung 'gunung Megido.'3

\footnotetext{
${ }^{1}$ Dave Hagelberg, Tafsiran Kitab Wahyu dari Bahasa Yunani (Jogyakarta: Yayasan Andi, 1997), p. 295.

2 J.I. Packer, Merill C. Tenney, William White, Jr., Ensiklopedi Fakta Alkitab, Bible Almanac 2 (Malang: Gandum Mas, 2004), p. 1509.

${ }^{3}$ Ensiklopedi alkitab Masa Kini Jilid 1, p. 369.
} 
Bukit Megido pada masa kehidupan Yohanes tingginya kira-kira 21 mil di sekitar Jajaran Karmel membenarkan bahasa Ibrani har, yang dipakai secara bebas dalam Perjanjian Lama untuk 'Daerah Bukit' dan 'Lereng pegunungan' (Yos 10:40; 11:16). 'Mata air Megido' (Hak 5:19) dan 'Lembag Megido' (2 Taw 35:22) telah menyaksikan peperangan peperangan penting sejak tahun $1468 \mathrm{sM}$ oleh Tutmosis III sampai peperangan jenderal Allenby pada tahun 1917. Fosdahl mencatat bahwa Harmagedon adalah tempat dimana banyak peperangan telah terjadi. ${ }^{4}$ 'Gunung Israel' tersebut menjadi saksi kekalahan raja Gog (Yeh 39:1,4). Hal ini mungkin ada dalam ingatan penulis Wahyu. ${ }^{5}$

\section{PERANG HARMAGEDONDALAM WAHYU 16:14-16; 19:11-21}

Catatan Yohanes sebagai penulis surat Wahyu tentang Perang Harmagedon terdapat dalam Wahyu 16:16. Dalam urutan profesi illahi, terletak pada saat "malaikat keenam menumpahkan cawannya ke atas sungai yang besar, Sungai Efrat, lalu keringlah airnya, supaya siaplah jalan bagi raja-raja yang datang dari sebelah timur" (Wahyu 16:12). Malapetaka cawan yang keenam merupakan persiapan untuk Perang Harmagedon, suatu perang yang akan dikisahkan lebih lanjut dalam Wahyu 19:17-21.

\section{PERSIAPAN-PERSIAPAN UNTUK PERANG HARMAGEDON}

Beberapa persiapan untuk perang Harmagedon ialah: Persiapan yang pertama adalah mengeringkan Sungai Efrat, dengan tujuan supaya tidak ada halangan fisik bagi tentara dan raja-raja yang akan datang lewat sebelah timur. Dalam Kejadian 15:18 dituliskan bahwa Sungai Efrat menjadi batas Tanah Perjanjian yang ideal. pada zaman Perjanjian Lama, di seberang Sungai efrat terdapat Asyur, musuh Israel yang mengancam umat Allah (Yesaya 7:20; 8:7; dan Yeremia 46:10). ${ }^{6}$ Pada zaman Rasul Yohanes Sungai Efrat adalah perbatasan Timur dari Kekaisaran Romawi. Kerajaan Parthia terletak di

\footnotetext{
${ }^{4}$ Frank Fosdahl, "Diktat Kuliah I Tesalonika dan Wahyu”, Jogyakarta: Sekolah Tinggi Teologia Injili Indonesia, 1991.

${ }^{5}$ J.D. Douglas, Ensiklopedi Alkitab Masa Kini Jilid 1 (Jakarta: Yayasan Komunikasi Bina Kasih/OMF, 2004), p. 369.

${ }^{6}$ George Eldon Ladd, A Commentary on the Revelation of John (Grand Rapids: William B. Eerdmans Publishing Company, 1972), p. 136.
}

sebelah timur Sungai Efrat. Roma dikalahkan oleh Parthia pada tahun $53 \mathrm{sM}$, dan lagi pada tahun 62 M. Kerajaan Parthia dianggap ancaman bagi kekuasaan Roma. ${ }^{7}$ Oleh karena itu, maka istilah "sungai besar Efrat itu" membawa kesan yang menakutkan bagi mereka pada zaman itu, tetapi yang dimaksudkan dalam nas ini jauh lebih dahsyat dari pada tentara Parthia atau tentara Asyur.

Persiapan yang kedua, yaitu penarikan pasukan dan raja dari seluruh dunia. Wahyu 16:13 menuliskan: "Dan aku melihat dari mulut naga dan dari mulut binatang dan dari mulut nabi palsu itu keluar tiga roh najis yang menyerupai katak." Sebagian dari hukuman cawan yang keenam keluar dari mulut naga. Naga di sini adalah gambaran yang diberikan Yohanes untuk Iblis ${ }^{8}$ dan dari mulut binatang yang dari laut, yaitu Anti Kristus. Untuk mengerti lebih dalam akan apa yang dimaksud dengan naga dan binatang tersebut maka perlu melihat penjelasan sebelumnya yaitu dalam Wahyu 13. Wahyu 13:1 menjelaskan tentang Yohanes yang berdiri di pantai laut. Lalu ia melihat seekor binatang yang keluar dari dalam laut, bertandung sepuluh dan berkepala tujuh; di atas tanduktanduknya terdapat sepuluh mahkota dan pada kepalanya tertulis nama-nama hujat. Istilah "berdiri di pantai laut" mememiliki ragam bacaan naskah kuno dalam pasal 12:18/31:1. Menurut tiga naskah kuno yang sangat lama, Yohanes menulis "Dan ia berdiri di pantai laut." Mayoritas naskah kuno berkata, "Dan saya berdiri di pantai laut." Kalau ragam naskah yang asli adalah "Dan ia berdiri di pantai laut" maka sebaiknya ayat itu dianggap sebagai ayat terakhir dari pasal 12, sehingga ayat ini dianggap sebagai ayat terakhir pasal 12 yaitu pasal 12:18. Tetapi kalau yang asli adalah "dan saya berdiri di pantai laut", maka sebaiknya ayat ini dianggap sebagai awal dari pasal 13:1.

Dari segi arti dan perkembangan kisah yang dikisahkan oleh Rasul Yohanes, dua-duanya dapat dibela, dua-duanya dapat dikatakan masuk akal. Penulis merasa bahwa danya ratusan naskah yang bertuliskan "dan saya berdiri di pantai laut" menjadi bukti yang lebih kuat daripada adanya tiga naskah yang paling tua yang berkata "Dan ia berdiri di pantai laut". Ternyata "Ia berdiri" adalah

${ }^{7}$ G.R. Beasley-Murray, Revelation (Grand rapids:

William B. Eerdmans Publishing Company, 1978), p. 164.

${ }^{8}$ Dalam bagian Wahyu 13 Iblis hanya disebutkan dalam ayat 2 dan 4 tetapi binatang yang muncul dari dalam laut mewakili dia. 


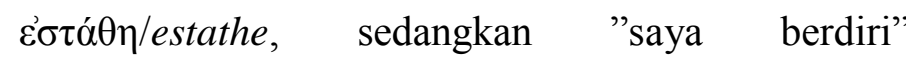

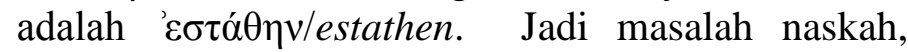
berkisar pada adanya satu huruf dalam bahasa Yunani. ${ }^{9}$

\section{TRINITAS SATAN DALAM PERANG HARMAGEDON}

Binatang yang pertama, yang dari laut, adalah seorang manusia yang dinamai Anti-Kristus. Istilah Anti-Kristus dipakai dalam 1 Yoh. 2:18, 22; 4;3; dan 2 Yoh 7. Baik pengajar-pengajar palsu maupun seorang jahat tertentu yang akan datang pada masa depan disebut "Anti-Kristus." Tokoh yang akan datang itu juga disebut "manusia durhaka" (2 tes. 2:3), "tanduk kecil" (dan 7:8), "raja" (dan 9:26; 11:36) dan "binatang" (wahyu 11:7; 14:9,11; 15:2, $16: 2$, 10, 13; 17:3-17; 19:19-20; 20:4, dan 10). Kedatangan Anti-Kristus yang digambarkan sebagai binatang yang keluar dari dalam laut, memiliki kesamaan dengan tuannya, yang datang dari dalam jurang maut (Pasal 9:2-11) dan yang akan ditutp kembali dalam jurang maut selama seribu tahun (Pasal 20:3). Selain kesamaan itu, dalam pasal 12:3 naga itu "berkepala tujuh dan bertandung sepuluh dan di atas kepalanya ada tujuh mahkota."

Binatang yang dilihat Yohanes bertanduk sepuluh, sama seperti binatang yang keempat yang diceritakan Daniel 7:7-8 dan 7:19-25. dalam Daniel pasal 7:24 sepuluh tanduk itu adalah "kesepuluh raja yang mnucul dari kerajaan itu." binatang itu juga berkepala tujuh. Dalam Wahyu 17:9-10 ketujuh kepala itu ditafsirkan sebagai tujuh gunung dan tujuh raja. Mungkin itu berarti bahwa tokoh jahat ini menguasai tujuh raja. Angka tujuh melambangkan bukan "kesempurnaan" tetapi "totalitas". ${ }^{10}$ Binatang itu jauh dari sempurna, tetapi kejahatannya sudah bersifat total.

Binatang itu digambarkan mempunyai sepuluh mahkota, sedangkan dalam pasal 19:12 dikatakan mengenai Kristus bahwa "...di atas kepala-Nya terdapat banyak mahkota..." Pada abad pertama kaisar-kaisar Roma semakin sering memakai sebutan ilahi tentang diri mereka sendiri, sampai Kaisar domitianus menyebut dirinya secara resmi sebagai "Tuhan dan allah". ${ }^{11}$ Nama-nama seperti itu dapat disamakan dengan nama-nama hujat yang dipakai oleh binatang itu. Oknum ini sudah disinggung dalam Kitab daniel 7 . ternyata nubuatan dalam Kitab daniel tentang "tanduk kecil" itu sementara digenapi dalam pribadi antiokhes Epifanes, tetapi penggenapan yang menyeluruh diceritakand alam Kitab Wahyu, mulai dari ayat ini. Oknum ini juga dinubuatkan dalam Injil Matius 24:15 dan Lukas 21:20.

Beberapa penafsir Wahyu berkata bahwa binatang ini melambangkan Kekaisaran Romawi, atau menunjuk ke salah satu kaisar. Menurut Walvoord, ${ }^{12}$ ayat ini menceritakan Kekaisaran Romawi yang akan dipulihkan kembali pada akhir zaman dan secara khusus, binatang ini adalah pemimpin Kekaisaran yang dipulihkan itu.

Wahyu 16:13 menuliskan pula: "...dan dari mulut nabi palsu itu..." Dan dari mulut binatang yang keluar dari dalam bumi (yaitu nabi palsu, pasal 13:11). Ini adalah binatang kedua yang dikisahkan sebelumnya dalam Wahyu 13:11-18. Dengan binatang yang kedua ini, ada tiga oknum jahat yang pokok yang dijuluki "Trinitas palsu", yang meniru Allah Tritunggal yang sejati. Semua kegiatan tiga oknum jahat yaitu Iblis, Anti-Kristus dan nabi palsu ini dapat dibandingkan dengan pekerjaan Trinitas dalam kehidupan orang-orang percaya. Sama seperti Kristus menerima kuasa dari Allah Bapa (Matius 11:27), Anti-Kristus menerima kuasa dari Iblis (Wahyu 13:4); Roh Kudus mempermuliakan Kristus (Yohanes 16:14), dan binatang yang kedua mempermuliakan Anti-Kristus (Wahyu 13:12); Kristus melayani supaya manusia menyembah Allah (Wahyu 1:6), Anti-Kristus bekerja supaya manusia menyembah Iblis (Wahyu 13:4); Kristus mempunyai sepuluh mahkota (wahyu 13:1) ${ }^{13}$ Dalam Wahyu 16:13 ketiga oknum jahat tersebut disebutkan dalam satu kalimat, "Dan aku melihat dari mulut naga dan dari mulut binatang dan dari mulut nabi palsu itu keluar tiga roh najis yang menyerupai katak."

Di dalam Wahyu 16:13 dituliskan bahwa hukuman Allah keluar dari mulut musuh Allah.

\footnotetext{
${ }^{9}$ Lihat catatan kaki dari Dave Hagelberg, Tafsiran Kitab Wahyu dari Bahasa Yunani (Jogyakarta: Yayasan Andi, 1997), p. 247.

${ }^{10}$ Richard Bauckham, The Climax of Prophecy: Studies on the Book of Revelation (Edinburgh: T \& T Clarck, 1993) p. 405.
}

${ }^{11}$ Dominus et Deus, menurut Beasley-Murray, p. 209.

12 John F. Walvoord, The Revelation of Jesus Christ (Chicago: Moody Press, 1966), p. 197.

${ }^{13}$ Mounce, p. 258; Beasley-Murray, p. 207; dan Bauckham, p. 284. 
Beasly-Murray ${ }^{14}$ dan Mounce ${ }^{15}$ menjelaskan bahwa tiga roh najis yang menyerupai katak adalah hasutan dari mereka yang menarik raja-raja pada peperangan yang dahsyat itu. Keluaran 8:1-5 berbicara tentang tulah kedua bagi orang Mesir yang berkisah tentang katak juga, sehingga sekali lagi ada kaitan antara Kitab Wahyu dan peristiwa pembebasan umat Allah dari Kerajaan Mesir.

Wahyu 16:14 menuliskan "Itulah roh-roh setan yang mengadakan perbuatan-perbuatan ajaib, dan mereka pergi mendapatkan raja-raja di seluruh dunia, untuk mengumpulkan mereka guna peperangan pada hari besar, yaitu hari Allah Yang Mahakuasa." Kata "setan" di sini secara harafiah adalah sebutan rohroh setan dapat diterjemahkan "roh-roh setan-setan" berasal dari kata Yunani $\pi \nu \in u ́ \mu \alpha \tau \alpha \delta \alpha \iota \mu \nu \nu i ́ \omega \nu$. Yohanes tidak berkata bahwa setan-setan itu mempunyai roh. Setan-setan yang disebutkan dalam ayat ini adalah roh-roh jahat, roh-roh yang hakekat atau sifatnya atau keberadaannya adalah jahat.

Dalam Wahyu 13:13 telah dibahas tentang nabi palsu yang mengerjakan pekerjaan-pekerjaan untuk mempermuliakan Anti-Kristus sehingga manusia di bumi menjadi percaya dan menyembah Anti-Kristus. Rupanya dalam Wahyu 16:14 puncak dari perbuatanperbuatan ajaib nabi palsu itu dinyatakan yaitu mereka pergi mendapatkan raja-raja di seluruh dunia, dengan tujuan untuk mengumpulkan mereka guna peperangan pada hari besar, yaitu hari Allah Yang Mahakuasa. Dalam Wahyu 16:12 dituliskan bahwa ada raja-raja yang akan datang dari sebelah timur, yang tidak terhalang oleh Sungai Efrat. Tetapi akan ada juga raja-raja dari seluruh dunia yang akan datang untuk ikut serta dalam perang itu. Suatu jumlah yang sangat besar yang akan dayang menyerang Israel, sedikit agak berlebihan dibandingkan dengan sebidang tanah kecil di Palestina dengan jumlah penduduk Israel yang hanya beberapa juta manusia saja. Rupanya di akhir jaman nanti akan terjadi suatu pemusatan kekuatan di Israel, kemungkinan terjadi koalisi anti Anti-Kristus yang berpusat di Israel, sehingga Anti-Kristus merasa perlu untuk mengumpulkan raja-raja seluruh dunia untuk datang menyerang Israel.

Dalam 1 Raja-raja 22:19-23 ada kisah mengenai suatu roh, yang mencalonkan drinya untuk pergi membujuk Raja Ahab "untuk maju berperang,

\footnotetext{
${ }^{14}$ Beasley-Murray, p. 244.

${ }^{15}$ Robert H. Mounce, The Book of Revelation (Grand
} Rapids: William B. Eerdmans Publishing Company, 1977), p.. 299. supaya ia tewas di Ramot-Gilead", dengan cara "menjadi roh dusta dalam mulut semua nabinya." Ternnyata apa yang dilakukan oleh satu roh untuk menewaskan seorang waja juga akan dilakukan oleh roh-roh yang keluar dari mulut tiga oknum jahat itu, supaya raja-raja dari seluruh dunia tewas, sebagai hukuman cawan keenam.

Sebutan hari Allah Yang Mahakuasa dalam

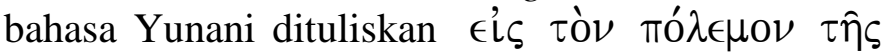

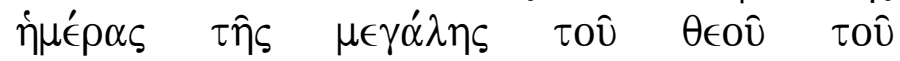

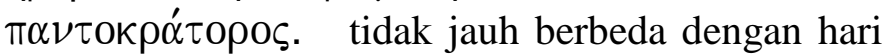
yang disebutkan dalam 1 Korintus 1:8; 3:13; filipi 1:10; 1 Tesalonika 5:2; 2 Tesalonika 1:10; dan 2 Petrus 3:12. Gagasan mengenai kumpulan bangsabangsa yang melawan Tuhan Allah bukan sesuatu yang baru karena sebelumnya juga sudah dinubuatkan dalam Kitab Zefanya 3:8 yang berbunyi:Oleh karena itu tunggulah Aku demikianlah firman TUHAN pada hari Aku bangkit sebagai saksi. Sebab keputusan-Ku ialah mengumpulkan bangsa-bangsa dan menghimpunkan kerajaan-kerajaan untuk menumpahkan ke atas mereka geram-Ku, yakni segenap murka-Ku yang bernyala-nyala, sebab seluruh bumi akan dimakan habis oleh api cemburu-Ku. ${ }^{16}$

Mereka berkumpul, tetapi mereka tidak sadar bahwa mereka dikumpulkan untuk dikalahkan pada hari Allah Yang Mahakuasa. Kebenaran ini jelas sekali dalam peringatan berikutnya dalam Wahyu 16:15 yang berbunyi: "Lihatlah, Aku datang seperti pencuri. Berbahagialah dia, yang berjaga-jaga dan yang memperhatikan pakaiannya, supaya ia jangan berjalan dengan telanjang dan jangan kelihatan kemaluannya.

\section{Peringatan tentang Kedatangan-Nya}

Frasa "Aku datang" dalam bahasa Yunaninya adalah " $€ \chi \varnothing \mu \alpha$ ८/erkhomai, dalam bentuk Present Tense, Middle, Indikatif, orang pertama, tunggal. Kata ini dipakai 36 kali dalam seluruh Kitab Wahyu, tetapi bentuk tersebut hanya dipakai sebanyak 7 kali dan diucapkan oleh Yesus sendiri berkenaan dengan kedatangannya dalam pasal 2:5, $16 ; 3: 11 ; 16: 15 ; 22: 7,12$, dan 20 . Kata ini akan lebih tepat diterjemahkan "Aku sedang datang" (dalam bahasa Inggris - I am coming).

\footnotetext{
${ }^{16}$ Zefanya 3:8
} 
Selanjutnya, sifat kedatangan Tuhan itu digambarkan seperti pencuri (bukan Kristus yang seperti pencuri, tetapi sifat dari kedatangan Kristus kedua kali ke dunia ini yang seperti pencuri). Ini bukan sesuatu yang baru karena sebelumnya dalam Injil Matius 24:42-44 Tuhan Yesus telah mengajarkan hal ini kepada murid-murid-Nya, demikian juga dalam I Tesalonika 5:2. Matius 24:42-44 menuliskan:

Karena itu berjaga-jagalah, sebab kamu tidak tahu pada hari mana Tuhanmu datang. Tetapi ketahuilah ini: Jika tuan rumah tahu pada waktu mana pada malam hari pencuri akan datang, sudahlah pasti ia berjaga-jaga, dan tidak akan membiarkan rumahnya dibongkar. Sebab itu, hendaklah kamu juga siap sedia, karena Anak Manusia datang pada saat yang tidak kamu duga.

I Tesalonika 5:22 menuliskan: "karena kamu sendiri tahu benar-benar, bahwa hari Tuhan datang seperti pencuri pada malam." Kata "malam" menunjuk pada keadaan di mana manusia beristirahat dan tidak menduga bahwa sesuatu akan terjadi.

Ungkapan berkat "Berbahagialah dia", dalam Wahyu 16:16 dipakai tujuh kali dalam Kitab Wahyu, yaitu: $1: 3 ; 14: 13 ; 16: 15 ; 19: 9 ; 20: 6 ; 22 ; 7$ dan 14. Ucapan bahagia ini hampir sama dengan apa yang diucapkan Yesus dalam Lukas 11:28. Menurut Bauckham ${ }^{17}$ ketujun ucapan bahagia ini menjadi inti dari seluruh beban Kitab wahyu. Ucapan bahagia diulangi tujuh kali karena kebahagiaan yang ada bagi setiap orang yang menuruti apa yang ada tertulis di dalam Kitab Wahyu adalah kebahagiaan yang sempurna. Buku Richard Bauckham menyelidiki Kitab Wahyu sebagai suatu buku sastra yang sangat rapi tersusun. Kata "berbahagialah" dalam bahasa Yunani dipakai dengan istilah $\mu \alpha \kappa \alpha ́ \rho\llcorner O \zeta$ adalah bentuk kata sifat dalam kasus nomatif, maskulin tunggal dari kata

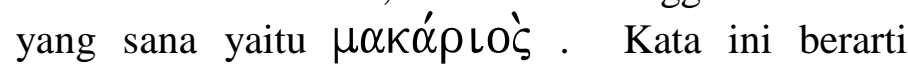
"diberkati, beruntung berbahagia, dan biasanya dipakai dalam pengertian suatu keistimewaan yang diterima dari kasih karunai ilahi Matius 11:6; 13:16; Lukas 11:27; 23:29; Johanes 13:17 I Petrus 3:14. Kata ini dalam Wahyu dipakai pertama dalam Wahyu 1:3 berbicara tentang berkat yang disediakan bagi orang yang membacakan dan yang mendengarkan kata-kata nubuat dalam kitab Wahyu dan yang menuruti apa yang ada tertulis di dalamnya, sebab waktunya sudah dekat.
Menurut tata bahasa asli - yang menggunakan kata sandang ( $\dot{\mathrm{o}} / \mathrm{ho})$ untuk dia yang membacakan, dan ada satu kata sandang (oi/hoi) untuk mereka yang mendengarkan...dan menuruti... jadi, kata sandang oi/hoi menggabungkan orang yang mendengarkan dengan orang yang menuruti. Ini adalah orang yang sama yang melakukan dua pekerjaan yang dihubungkan kata sambung kaì yaitu pekerjaan mendengarkan dan menuruti - tidak ada berkat untuk orang yang hanya mendengarkan kitab ini saja, karena mereka harus juga menuruti apa yang ada tertulis di dalamnya. Dan ternyata ayat ini adalah kunci untuk bisa mengerti tujuan utama dari Kitab Wahyu dituliskan yaitu supaya orang yang menuruti apa yang tertulis di dalamnya akan berbahagia karena saat waktunya sudah dekat.

Dalam Wahyu 16:15 berkat kebahagiaan yang sama diberikan kepada orang yang berjaga-jaga dan yang memperhatikan pakaiannya... Konsep yang benar tentang keselamatan adalah bahwa bukan saja orang-orang percaya sudah diselamatkan sehingga dapat bersantai dengan keselamatan mereka, tetapi mereka perlu untuk senantiasa berjaga-jaga dengan kehidupannya dan memperhatikan pakaiannya, supaya ia jangan berjalan dengan telanjang dan jangan kelihatan kemaluannya. Dalam pasal 3:3 juga terdapat perkataan Tuhan Yesus Aku datang seperti pencuri, dan dalam pasal 3:2 ada perintah untuk berjagajaga. Kata yang diterjemahan "Bangunlah" dalam pasal 3;2 diterjemahkan "berjaga-jaga" dalam pasal $16: 15$.

Ketelanjangan sebelumnya telah disebutkan dalam Wahyu 3:17-18 yaitu ditujukan kepada gereja Tuhan di Laodikia, dimana Tuhan tahu segala pekerjaan mereka. Keberatan Tuhan tentang pekerjaan mereka adalah bahwa mereka memiliki sifat "tidak dingin dan tidak panas". Mereka dikatakan "suam-suam $\mathrm{ku}$, dan tiak dingin atau panas." Akibatnya ialah bahwa Tuhan akan memuntah mereka dari mulut-Nya, karena mereka tidak dingin dann tidak panas. Kritikan Tuhan selanjutnya untuk jemaat ini adalah: Karena engkau berkata: 'Aku kaya dan aku telah memperkayakan diriku dan aku tidak kekurangan apa-apa, dan karena engkau tidak tahu, bahwa engkau melarat, dan malang, miskin, buta dan telanjang,' Jadi apa yang dikatakan di sini bukanlah sesuatu hal yang baru, tetapi dalam konteks ini menjadi satu kejutan bagi pembaca. Peringatan untuk para pembaca akan kedatangan Tuhan ini mirip sekali dengan 
peringatan yang diucapkan kepada umat Tuhan dalam Wahyu 18:4 yang berbunyi: Lalu aku mendengar suara lain dari sorga berkata: "Pergilah kamu, hai umat-Ku, pergilah dari padanya supaya kamu jangan mengambil bagian dalam dosadosanya, dan supaya kamu jangan turut ditimpa malapetaka-malapetakanya."

Kepada jemaat di Laodikia, firman Tuhan menyatakan keadaan mereka yang menganggap diri mereka kaya, tetapi Tuhan menilai mereka sebaliknya, yaitu bahwa mereka melarat, malang, miskin, buta dan telanjang. Hal ini ironis mengingat keadaan jemaat Laodikian yang sebenarnya secara jasmani mereka kaya dengan kekayaan, keadaan masyarakat yang sangat makmur. Tetapi di depan mata Yesus mereka dianggap sebagai orang miskin. Ada semacam tumbuhan yang tumbuh di sekitar Laodikia yang dapat dipakai untuk melumas mata. Tetapi Tuhan mengatakan bahwa mereka buta. Mereka juga memiliki, membuat dan memasarkan kain wol hitam, tetapi di depan mata Tuhan dikatakan telanjang! Hal ini sangat ironis.

Ada tiga macam tuntutan Tuhan bagi mereka yaitu: supaya mereka membeli dari Tuhan tiga macam benda yaitu emas, pakaian putih, dan minyak untuk melumas mata. Memang mereka suda mempunyai emas, tetapi emas itu dianggap tidak murni. Emas surgawilah yang murni. Emas itu dapat dibeli dengan ketaatan. Yang ditawarkan untuk dibeli bukan keselamatan. ${ }^{18}$ Dalam Kitab Wahyu tawaran keselamatan bersifat lain. Misalnya Wahyu 22:17, ada tawaran yang jelas menunjuk pada keselamatan yang kekal: "Dan barangsiapa yang haus, hendaklah ia datang dan barangsiapa yang mau, hendaklah ia mengambil air kehidupan dengan Cuma-Cuma!" apa yang ditawarkan untuk dibeli di sini bukanlah keselamatan.

Mereka sudah mempunyai keselamatan.Yang ditawarkan untuk dibeli adalah kekayaan surgawi, yang diperoleh melalui usaha orang-orang percaya. Dengan usaha-usahanya, orang-orang percaya akan memperoleh pahala, mahkota, dan dengan usahausahanya orang-orang percaya akan meraih janji yang ditawarkan kepada "barang siapa yang menang". Hal ini jangan dicampur adukkan dengan hal keselamatan yang didapat orang-orang percaya bukan melalui perbuatan, tetapi semata-mata hanya oleh kasih karunia dan sifatnya cuma-Cuma.

\footnotetext{
${ }^{18}$ Beasley_Murray, p. 106.
}

Mereka dinasihatkan untuk membeli pakaian putih dalam Wahyu 3 sementara dalam Wahyu 16 mereka didorong supaya memperhatikan pakainannya supaya mereka jangan berjalan dengan telanjang dan jangan kelihatan kemaluannya. Istilah "kemaluan" di dalam Mishnah (ajaran rabi-rabi Israel) ketua jaga Bait Allah biasa menguji kesiagaan penjaga-penjaga Bait Allah pada malam hari. Jikalau ada penjaga yang tertidur pakaiannya diambil pakaiannya diambil darinya dan dibakar, dan dia disuruh pulang dalam keadaan telanjang dan malu. ${ }^{19}$ Kata Telanjang dalam bahasa Yunani

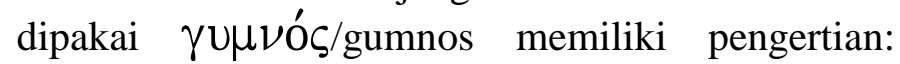
telanjang, tanpa pakaian. (TDNT 1:773,133).Bandingkan dengan Yehezkiel 23:24-29 dan 2 Korintus 5:3.

Kitab Wahyu ditulis untuk Yohanes, orangorang percaya masa itu dan masa depan. Disini diberikan peringatan supaya orang-orang percaya siap siaga menantikan kedatangan. Jika orangorang percaya siap, mereka tidak akan telanjang dan akan diberi pakaian. Telanjang juga mengingatkan akan Adam dan Hawa yang jatuh ke dalam dosa dan telanjang. Mereka malu dan coba menyembunyikan diri dari Allah. Orang yang sengaja berbuat dosa dan tidak bersifat siap mengakui dosa berani menghadapi Yesus dalam kemuliaan dalam dosanya. Tentu orang itu akan malu di depan-Nya.

Baru kemudian, perang disebut di dalam Wahyu 16:16. Harmagedon adalah tempat dimana banyak peperangan telah terjadi, dan akan menjadi tempat peperangan terakhir masa Tribulasi. Hubungan dengan ayat sebelumnya adalah jangan orang beriman terlibat dalam sistem dunia yang dikutuk Allah dan yang menghujat namaNya. ${ }^{20}$

Wahyu 16:16 berbunyi: "Lalu Ia mengumpulkan mereka di tempat yang dalam bahasa Ibrani disebut Harmagedon." Kata "harmagedon" ini hanya dipakai satu kali saja di dalam seluruh Alkitab, yaitu di sini. Nama tersebut tidak terdapat dalam peta-peta dunia, dan karena itu beberapa penafsir Alkitab khususnya dari golongan Amillenium (mereka yang tidak percaya bahwa Kerajaan Seribu Tahun/Millenium akan ada secara fisik di dunia ini) berpendapat bahwa Harmagedon ini hanya lah sebuah simbol yang seharusnya dilihat

\footnotetext{
${ }^{19}$ Robert H. Mounce, p. 301.
}

${ }^{20}$ Frank Fosdahl, "Diktat Kuliah I \& II Tesalonika Wahyu”. Jogyakarta: Sekolah Tinggi Teologia Injili Indonesia, 1991. 
dari terang sejarah perjanjian. Jacob P. Goen menuliskan: karena bukan nama geografis melainkan nama yang menandai peristiwa dalam terang sejarah perjanjian. Nama Harmagedon terkait dengan Megido, daerah ayng berulang kali menjadi medan perang. Misalnya pada waktu Israel sepenuhnya dikuasai oleh musuh-musuhnya yaitu Yabin dan Sisera, dengan cara yang tak terduga Allah menyelamatkan bangsa-Nya melalui tangan Barak dan debora (Hak 4 dan 5). Musuh-musuh itu dihancurkan sama sekali. Peristiwa itu menjadi contoh yang dipakai oleh para nabi untuk menggambarkan kebinasaan musuh-musuh Israel di kemudian hari. Demikian pula Wahyu menyatakan bahwa bangsa-bangsa yang dikumpulkan di Harmagedon akan dihancurkan secara tiba-tiba, dengan cara yang tak terduga, seperti terjadi pada bangsa-bangsa kafir pada zaman Barak dan debora. Dengan menyebut Megido, Wahyu menyatakan bahwa bangsa-bangsa itu menuju ke kebinasaan. Allah akan meniadakan segala kekuasaan yang memegahkan diri di atas bangsa-Nya. ${ }^{21}$ William Hendrickson melanjutkan bahwa:

Harmagedon menjadi simbol bagi setiap pertempuran di mana orang-orang Israel berada dalam penindasan dan dalam kebutuhan yang sangat, Tuhan tiba-tiba menyatakan kuasa-Nya demi umatNya yang tertindas dan mengalahkan musuh itu. . . Tetapi Harmagedon yang sesungguhnya, yang besar, yang akhir, terjadi bersamaan waktunya dengan masa singkat Iblis. Ketika dunia, di bawah kepemimpinan Iblis, pemerintah antikristen, dan agama antikristen - naga binatang dan nabi palsu dikumpulkan melawan Gereja untuk pertempuran terakhir, dan kebutuhan menjadi sangat besar, ketika anak-anak Allah yang ditindas pada setiap sisi, berteriak minta pertolongan; maka tiba-tiba secara dramatis, Kristus menampakkan diri-Nya membebaskan umat-Nya. Kesengsaraan akhir itu dan penampakkan diri Kristus itu di awan-awan kemuliaan untuk membebaskan umat-Nya, itulah Harmagedon. $^{22}$

Kedua pandangan tentang Harmagedon di atas sangat tidak cocok dengan pemaparan yang disampaikan oleh Yohanes dalam Kitab Wahyu.

${ }^{21}$ Jacob P.D. Goen, Aku Datang Segera, Tafsiran Kitab Wahyu (Surabaya: Momentum Christian Literatur, 2002) p. 228.

${ }^{22}$ William Hendricksen, Lebih dari Pemenang, Sebuah Interpretasi Kitab Wahyu (Surabaya: Momentum Christian Literatur, 2007) p. 193.
Kenyataan bahwa ada urutan-urutan peristiwa yang seharusnya ditaati yang menujuk kepada kenyataan bahwa peperangan besar yang disebutkan sebagai Harmagedon itu sesungguhnya akan sungguhsungguh terjadi. Peperangan ini akan menjadi penutup suatu masa penyiksaan yang besar bagi orang-orang yang percaya kepada Allah dan tidak menyembah Anti-Kristus.

\section{Kemenangan Akhir Harmagedon}

Perang Harmagedon akan ditutup dengan Kedatangan Kristus Kedua kali di dunia ini untuk mengalahkan dan membinasakan musuh-musuhNya. Wahyu 19:11-16 menjelaskan hal ini. Sementara di antaranya, terdapat sisipan kisah tentang Pelacur Besar yaitu Babel (Pasal 17:119:10) dan kisah Pengantin Kristus yaitu Yerusalem Baru (pasal 21:9 - 22:10) terdapat kisah peralihan kerajaan, ${ }^{23}$ atau kisah kedatangan Kristus. Di sini kisah kemenangan-Nya atas segala yang melawan Dia sangatlah ditekankan. Beberapa penafsir berkata bahwa Alkitab tidak mengatakan dengan jelas tentang bagaimana caranya Tuhan akan kembali ke dunia. Namun demikian satu-satunya referensi yang mungkin membantu adalah ucapan malaikat dalam Kisah Para Rasul 1:11 kepada para murid yang sedang termangu-mangu memandang Yesus yang telah naik ke surga. Malaikat berkata: "Hai orangorang Galilea, mengapakah kamu berdiri melihat ke langit? Yesus ini, yang terangkat ke surga meninggalkan kamu, akan datang kembali dengan cara yang sama seperti kamu melihat Dia naik ke surga." Jika Yesus Kristus dibangkitkan dan naik ke surga secara badaniah, maka Dia akan kembali secara badaniah. Ia akan dapat terlihat secara mata fisik oleh manusia di dunia ini.

Wahyu 19:11 menuliskan: "Lalu aku melihat surga terbuka: sesungguhnya, ada seekor kuda putih; dan Ia yang menungganginya bernama: "Yang Setia dan Yang Benar", Ia menghakimi dan berperang dengan adil." Walaupun pasal 19:9-10 di atas merupakan peralihan, tetapi dalam ayat ini terkesan bahwa Tuhan datang secara mendadak. Nama Yang Setia dan Yang Benar mengingatkan kita pada pasal 3:14. Tuhan Yesus tidak datang untuk balas dendam secara sembarangan, tetapi untuk menghakimi dan berperang dengan adil. Istilah "surga terbuka" menunjukkan suatu keadaan dimana sesuatu yangbesar akan terjadi dan semuanya itu dimulai dari surga yang menjadi

\footnotetext{
${ }^{23}$ Bauckham, p. 5-6.
} 
tempat kediaman Allah. Surga selalu dibedakan dengan dunia tempat dimana manusia dan segala ciptaan berada.

Di sini Kristus digambarkan meninggalkan surga secara jasmani dan datang ke bumi. Kuda putih itu melambangkan kemenangan. Sudah menjadi kebiasaan bagi jenderal-jenderal Romawi sesudah menang untuk mengandakan pawai di atas kuda putih dengan diikuti oleh para tawanan perang dalam satu prosesi kemenangan. Kenyataan bahwa Kristus datang dengan menunggang kuda putih menandakan bahwa itu adalah saat kemenangan-Nya dan untuk menghukum dunia yang jahat. ${ }^{24}$

Wahyu 19:12-13 merupakan gambaran tentang pribadi Kristus yang akan datang kedua kalinya. Dicatat di sana bahwa mata-Nya bagaikan nyala api dan di atas kepala-Nya terdapat banyak mahkota. Istilah mahkota di sini dipakai dengan kata Yunani $\delta 1 \alpha \delta \eta \mu \alpha /$ diadema yang hanya dipakai tiga kali dalam kitab Wahyu, yaitu dalam Wahyu 12:3; 13:1; dan 19:12. Ada dua kata Yunani yang dipakai dalam Kitab Wahyu yang diterjemahkan dengan mahkota. Yang pertama ialah $\delta i \alpha \delta \eta \mu \alpha /$ diadema dan yang kedua adalah $\sigma \tau \varepsilon \varphi \alpha v o s /$ stefanos yang juga diterjemahkan mahkota dalam Wahyu 2:10; 3:11;

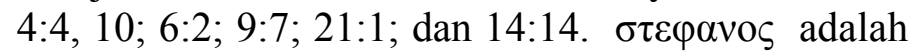
mahkota yang diterima sebagai hadiah atau upah, seorang pemenang dalam pertandingan akan menerima $\sigma \tau \varepsilon \varphi \alpha v o{ }^{25}$ Mahkota $\sigma \tau \varepsilon \varphi \alpha v o \varsigma$ adalah mahkota yang dipakai oleh Anti-Kristus karena ia telah mengalahkan bangsa-bangsa. Ia mendapatkan kekuasaan melalui perebutan kekuasaan. Ia mengalahkan bangsa-bangsa untuk mendapatkan kekuasaan atas mereka. Sementara $\delta 1 \alpha \delta \eta \mu \alpha$ adalah mahkota yang dipakai oleh Tuhan Yesus bukan karena Ia harus berperang atau bertanding untuk mengalahkan dan mendapatkan mahkota-Nya. $\Delta 1 \alpha \delta \eta \mu \alpha$ adalah mahkota kerajaan, mahkota yang dimiliki oleh raja-raja yang memerintah yang menujukkan kedaulatannya.

Pada-Nya ada tertulis suatu nama yang tidak diketahui seorangpun, kecuali Ia sendiri. Banyak orang berusaha menduga-duga mengenai siapa nama dari frase nama yang tidak diketahui seorangpun, kecuali Ia sendiri. Tetapi pemaparan dari ayat tersebut sangat jelas bahwa tidak ada seorangpun

\footnotetext{
${ }^{24}$ John F. Walvoord, Pedoman lengkap Nubuat Alkitab (Bandung: Yayasan Kalam Hidup, 2003) p. 801. ${ }^{25}$ Harold K. Moulton, Leksikon analitis Bahasa Yunani yang Direvisi, Diterjemahkan oleh Tandi Randa (.Jogyakarta: Randa's family Press, 2009) p. 349.
}

yang akan mengetahui nama tersebut, kecuali Yesus sendiri, jadi tidak akan ada manfaatnya mendugaduga atau membuang waktu lama untuk menyelidikinya. Namun ada suatu nama lain yang dapat diketahui dalam ayat 13 yaitu bahwa Ia memakai jubah yang telah dicelup dalam darah dan nama-Nya ialah: "Firman Allah." Nama ini telah menjadi milik-Nya bahkan pribadi-Nya sebelum dunia dijadikan dan sangat cocok dengan pemaparan sangat awal Yohanes dalam tulisannya di Yohanes 1:1 ketika ia menuliskan: "pada mulanya adalah Firman, Firman itu bersama-sama dengan Allah dan Firman itu adalah Allah.” Bentuk imperfek yang digunakan untuk kata kerja to be $\hat{\eta} \nu$ dalam ayat ini dan bentuk keterangan waktu $\epsilon$ $\propto \rho \chi \hat{n}$ menujukkan bahwa di dalam kekekalan telah berlangsung ada dan sedang terus pula berlangsung ada Firman dan Firman itu telah berlangsung ada dan sedang terus pula berlangsung ada bersamasama dengan Allah (menunjukkan suatu persekutuan yang sangat erat, intim dan dalam, tak terpisahkan dengan pribadi Allah - ó @eos ada artikel), dan Firman itu sendiri telah berlangsung ada dan sedang terus menerus adalah Allah ( $\Theta \varepsilon o s$ tanpa artikel).

Yang terjadi pada akhir perang Harmagedon adalah bahwa setelah surga terbuka, maka Yesus akan datang kembali ke dunia dan semua pasukan yang di surga mengikuti Dia; mereka menunggang kuda puth dan memakai lenan halus yang putih bersih (Wahyu 19;14). "Semua pasukan yang di surga mengikuti Dia" menjadi suatu indikasi bahwa pasukan yang akan datang ini akan sangat besar dan meriah karena semua pasukan yang di surga dijelaskan akan turun ke dunia mengikuti-Nya. Mereka akan menunggang kuda putih dan memakai lenan halus yang putih bersih. Pertanyaannya adalah apakah ini malaikat atau manusia? Atau keduanya? Kalau ayat ini merupakan penggenapan dari Wahyu 17:14, maka ayat ini menggambarkan keadaan mereka yang sudah menerima dan menuruti segala yang diperintahkan dalam Wahyu 2-3. Tidak dikatakan bahwa mereka akan ikut berperang, melain bahwa mereka hanya mengikuti Dia saja. Sama seperti Tuhan menunggang kuda putih, mereka juga akan ikut dalam kekudusan dan kemenangan Juru Selamat dan Raja mereka. Dan sesuai dengan janji yang dicatat dalam pasal 3:5, mereka memakai lenan halus yang putih bersih.

Cara Yesus menghancurkan musuh-musuhNya dinyatakan dalam Wahyu 19:15 yaitu bahwa 
dari mulut-Nya keluarlah sebilah pedang tajam yang akan memukul segala bangsa. Apakah benar dari mulut-Nya akan keluar sebilah pedang dan bagaimana caranya pedang tersebut dapat memukul segala bangsa bukanlah sesuatu yang tidak mungkin dalam gambaran fiktual manusia. Karena seperti alam semesta diciptakan dengan Firman Allah, sementara Yesus sendiri adalah Firman itu, maka tidak lah sulit bagi Yesus untuk memukul para musuh-Nya, sebanyak apapun mereka, dengan menggunakan perkataan-Nya.

Ia diikuti oleh semua pasukan yang disurga yang juga menunggang kuda putih, yang menggambarkan mereka sebagai pemenang, dan mengenakan lenan halus yang putih bersih, yang menggambarkan kemurnian. Kristus digambarkan sebagai mempunyai sebilah pedang tajam di mulutNya, dan kata untuk "pedang" menandakan satu pedang yang panjang dan biasanya besar yang terkenal dengan nama pedang Thracia (Kata Yunani yang dipakai $\rho \circ \mu \phi \alpha i ́ \alpha /$ rhomphaia). Tentu saja Ia mengatakan kata-kata dan akan mampu menghukum orang-orang jahat. Mazmur 2:9 juga dikutip disini, yang menunjuk kepada pemerintahan-Nya dengan menggunakan gada besi (why 19:15). PemerintahanNya akan menjadi kerajaan absolute, tetapi benar dan adil dengan sempurna. Ia juga akan menjadi Dia yang membaca hukuman atas orang-orang jahat, dan simbolisme tentang kilangan anggur yang akan memeras anggur digunakan untuk menggambarkan hukuman-Nya atas orang-orang jahat,'Dan pada jubah-Nya dan paha-Nya tertulis suatu nama, yaitu: Raja segala raja dan Tuan di atas segala tuan" (ayat 16).

Bagaimanapun pendeknya gambaran mengenai kedatangan Kristus yang kedua ini, tetapi jelas bahwa ketika Kristus datang dalam kuasa, Ia akan membawa hukuman-Nya atas dunia, dan mendirikan Kerajaan Seribu Tahun. Kitab lain dalam Alkitab memiliki beberapa rincian mengenai kedatangan yang kedua itu. Dalam zakharia 14:3,4 dibuat satu nubuat, "Kemudian Tuhan akan maju berperang melawan bangsa-bangsa itu sendiri Ia berperang pada hari pertempuran. Pada waktu itu kaki-Nya akan berjejak di bukit Zaitun yang terletak didepan Yerusalem di sebelah timur. Bukit Zaitun itu akan terbelah dua dari timur ke barat, sehingga terjadi suatu lembah yang sangat besar; setengah dari bukit itu akan bergesar ke utara dan setengah lagi ke selatan. "Periatiwa ini membedakan antara kedatangan Kristus yang kedua sejak Pengangkatan karena saat itu bukan waktunya.
Yesus sendiri menggambarkan kedatanganNya yang kedua dalam Matius 24:27-31,"Sebab sama seperti kilat memancar dari sebelah timur dan melontarkan cahayanya sampai ke barat, demikian pulalah kelak kedatangan Anak Manusia. Dimana ada bangkai, di situ burung nazar berkerumun. Segala sesudah siksaan pada masa itu, matahari akan menjadi gelap dan bulan tidak bercahaya dan bintang-bintang akan berjatuhan dari langit dan kuasa-kuasa langit akan goncang. Pada waktu itu akan tampak tanda Anak Manusia di langit dan semua bangsa di bumi akan meratap dan mereka akan melihat Anak Manusia itu datang diatas awanawan dilangit dengan segala kekuasaan dan kemuliaan-Nya. Dan Ia akan menyuruh keluar malaikat-malaikatNya dengan meniup sangkakala yang dasyat bunyinya dan mereka akan mengumpukkan orang-orang pilihan-Nya dari keempat penjuru bumi, dari ujung langit yang satu ke ujung langit yang lain.'Kedatangan Kristus yang kedua dan kehadiran-Nya mencapai klimaksnya dengan menghakimi seluruh dunia itu dan membawa kerajaan kebenaran Kristus.

Dan Ia akan memerintah mereka dengan gada besi dan Ia akan memeras anggur dalam kilangan anggur, yaitu kegeraman murka Allah Yang Mahakuasa. Kata "memerintah" dipakai kata Yunani $\pi i ́ \mu \alpha \imath \omega /$ poimaino yang secara harafiah berarti "menggembalakan" tetapi melihat pemakaian kata ini misalnya dalam Matius 2:6; Kisah Para Rasul 20:28; Wahyu 12:15; dan 19:15, belum tentu gembala yang dimaksudkan lemah lembut. ${ }^{26}$

Ia diikuti oleh semua pasukan yang disurga yang juga menunggang kuda putih, yang menggambarkan mereka sebagai pemenang, dan mengenakan lenan halus yang putih bersih, yang menggambarkan kemurnian. Kristus digambarkan sebagai mempunyai sebilah pedang tajam di mulutNya, dan kata untuk "pedang" menandakan satu pedang yang panjang dan biasanya besar yang terkenal dengan nama pedang Thracia (Yun.: hromphaia). Tentu saja Ia mengatakan kata-kata dan akan mampu menghukum orang-orang jahat. Mazmur 2:9 juga dikutip disini, yang menunjuk kepada pemerintahan-Nya dengan menggunakan gada besi (why 19:15). Pemerintahan-Nya akan menjadi kerajaan absolute, tetapi benar dan adil dengan sempurna. Ia juga akan menjadi Dia yang

\footnotetext{
${ }^{26}$ Dave Hagelberg, Tafsiran Kitab Wahyu dari
}

Bahasa Yunani (Jogyakarta: Penerbit Yayasan Andi, 2005) p. 82 
membaca hukuman atas orang-orang jahat, dan simbolisme tentang kilangan anggur yang akan memeras anggur digunakan untuk menggambarkan hukuman-Nya atas orang-orang jahat,'Dan pada jubah-Nya dan paha-Nya tertulis suatu nama, yaitu: Raja segala raja dan Tuan di atas segala tuan" (ayat 16).

Yohanes mencatat beberapa hal yang akan terjadi sesudah kedatangan Kristus yang kedua, "Lalu aku melihat seorang malaikat berdiri dalam matahari dan ia berseru dengan suara nyaring kepada semua burung yang terbang di tengah langit, katanya: 'Marilah ke sini dan berkumpullah untuk turut dalm perjamuan Allah, perjamuan yang besar, supaya kamu makan daging semua raja dan daging semua panglima dan daging semua pahlawan dan daging semua kuda daging semua penunggangnya dan daging semua orang, baik yang merdeka maupun hamba, baik yang kecil maupun yang besar.' Dan aku melihat binatang itu dan raja-raja dibumi serta tentara-tentara mereka telah berkumpul untuk melakukan peperangan melawan penunggang kuda itu dan tentaraNya " (Wahyu 19: 17-19). Kenyataan bahwa malaikat itu berseru dengan suara nyaring menunjukkan ada hal penting yang akan segera terjadi (bandingkan dengan 6:10, 7:2, 10; 10:3; $14: 15 ; 18: 2)$. Undangan kepara semua burung untuk turut dalam perjamuan makan daging orang-orang yang terbunuh dalam hukuman atas bala tentara itu bertentangan dengan undangan yang diberikan sebelumnya dalam pasal ini, yaitu kepada mereka yang diundang kepada perjamuan nikah anak Domba. Ada Kesamaan yang terdapat dalam nubuat-nubuat Yehezkiel 39:17-20 pada akhir serangan terhadap Israel dari utara dengan mayatmayat yang dimakan burung-burung. Namun demikian, Yehezkiel merujuk kepada peperangan sebelumnya yang terjadi dalam paruh pertama dari tujuh tahun terakhir dan bukan pada saat ini, tetapi kesempurnaan itu jelas. Namun demikian, keserupaan bukan berarti keidentikan. Pandangan yang benar-benar sejajar dengan ini terdapat dalam Matius 24:28, dimana sekali lagi burung-burung makan mayat. ${ }^{27}$

Hukuman yang mengerikan yang dijatuhkan kepara bala tentara yang bersatu melawan bala tentara surgawi itu memperjelas bahwa Allah tidak memangdang manusia, dan orang-orang tidak percaya yang besar dimata dunia, tidak lebih baik ketimbang orang lain rendah. Langkah selanjutnya

${ }^{27}$ Donald Guthrie, Tafsiran Alkitab Masa Kini Jilid 3 (Jakarta: BPK Gunung Mulia, 1981), p.803. membawa hukuman atas binatang, yaitu penguasa dunia, dan nabi palsu yang bersekutu dengan dia. Yohanes mencatat. "Maka tertangkaplah binatang itu dan bersama-sama dengan dia nabi palsu, yang telah mengadakan tanda-tanda didepan matanya, dan dengan demikian ia menyesatkan yang telah menerima tanda dari binatang itu dan yang telah menyembah patungnya. Keduanya dilemparkan hidup-hidup ke dalam lautan api yang menyalanyala oleh belerang" (ayat 20).

Di sini perlu perbedaan yang teliti antara lautan api ini dengan Hades. Mereka yang tidak selamat dan mati sebelum kedatangan Kristus yang kedua akan masuk ke dalam Hades, sebagaimana digambarkan oleh orang kaya sesudah kematiannya (Luk 16:23). Sampai saat itu tidak seorang pun yang dilemparkan ke dalam lautan api. Namun demikian, binatang dan nabi palsu itu, sekarang dilemparkan secara langsung ke dalam lautan api itu, dan seribu tahun kemudian mereka akan dikumpulkan dengan orang-orang yang sekarang ada dalam Hades atau mereka yang tidak diselamatkan pada akhir Kerajaan Seribu Tahun itu. Tentu saja hal ini menandai akhir kekuasaan bukan - Yahudi dan kerajaan dunia yang ada di bawah kekuasaan penguasa, yaitu binatang yang keluar dari dalam laut, dan binatang yang keluar dari dalam bumi, yaitu nabi palsu yang bersekutu dengan binatang yang keluar dari dalam laut itu (Wahyu 13:1-8). Sebagaimana didukung oleh kenyataan bahwa binatang dan nabi palsu itu masih ada dalam lautan api sampai akhir masa seribu tahun, maka jelaslah bahwa lautan api itu tidak kosong, dan lautan api itu juga tidak berfungsi sebagai tempat yag menyucikan, karena mereka yang ada dalamnya tetap berada dalam sifatnya yang fasik dengan tubuh yang cocok untuk hukuman yang kekal. Sebaliknya, orang yang percaya dalam Kristus akan memiliki tubuh baru yang cocok untuk penyembahan dan pelayanan kepada Allah selama masa kekekalan. Hukuman Kristus atas bala tentara ini disimpulkan sebagai, "dan semua orang lain dibunuh dengan pedang, yang keluar dari mulut penunggang kuda itu; dan semua burung kenyang oleh daging mereka" (Wahyu 19:21).

\section{KESIMPULAN}

Perang Harmagedon adalah suatu peperangan yang akan sungguh-sungguh terjadi di dunia ini. Ini bukan suatu lambang atau simbol dari situasi atau keadaan dunia. Harmagedon akan sungguh terjadi 
secara literal di dunia, yaitu suatu peperangan besar yang terjadi antara Anti-Kristus dan pasukannya melawan Allah Yang Mahakuasa dan umat-Nya. Peperangan ini terjadi karena bangsa-bangsa akan terbujuk tipuan dari nabi palsu yang menipu seluruh dunia untuk menyembah Anti-Kristus. Ini adalah kegiatan trinitas palsu Iblis yaitu Iblis - Anti-Kristus - nabi palsu.Perang Harmagedon akan terjadi dalam kronologi cawan keenam dalam penglihatan yang dinyatakan kepada Yohanes. Perang ini akan dimulai dengan keringnya sungai Efrat untuk menjadi jalan bagi bangsa-bangsa menyeberang menyerang Israel. Kemudian bangsa-bangsa akan datang untuk berperang melawan Allah dan Yang Diurapi-Nya. Mereka akan mengepung kota suci Yerusalem, hingga umat Allah akan terkepung. Perang ini akan ditutup dengan kedatangan Yesus Kristus yang kedua kali di dunia ini bersama salehsaleh-Nya. Tuhan Yesus akan membunuh musuhmusuh-Nya dengan pedang yang keluar dari mulutNya. Akhir dari pada nasib nabi palsu dan AntiKristus adalah dibuang ke dalam lautan api, sementara Iblis akan dirantai dalam lubang yang dalam untuk kurun waktu seribu tahun. Setelah itu, ia akan dilepaskan untuk sedikit waktu saja. Tuhan Yesus akan memerintah selama seribu tahun di dunia ini dalam Kerajaan Millenium.

\section{KEPUSTAKAAN}

[1] Alkitab. Jakarta: Lembaga Alkitab Indonesia. 1984.

[2] Bauckham, Richard. The Climax of Prophecy: Studies on the Book of Revelation (Edinburgh: T \& T Clarck, 1993.

[3] Beasley-Murray, G.R. Revelation. Grand rapids: William B. Eerdmans Publishing Company, 1978.

[4] Douglas, J.D. Ensiklopedi Alkitab Masa Kini Jilid 1. Jakarta: Yayasan Komunikasi Bina Kasih/OMF, 2004.

[5] Fosdahl, Frank. "Diktat Kuliah I Tesalonika dan Wahyu", Jogyakarta: Sekolah Tinggi Teologia Injili Indonesia, 1991.

[6] Goen, Jacob P.D. Aku Datang Segera, Tafsiran Kitab Wahyu. Surabaya: Momentum Christian Literatur, 2002.
[7] Guthrie, Donald. Tafsiran Alkitab Masa Kini Jilid 3. Jakarta: BPK Gunung Mulia, 1981.

[8] Hagelberg, Dave. Tafsiran Kitab Wahyu dari Bahasa Yunani. Jogyakarta: Yayasan Andi, 1997

[9] Tafsiran Kitab Wahyu dari Bahasa Yunani. Jogyakarta: Penerbit Yayasan Andi,

[10] 2005.Hendricksen, William. Lebih dari Pemenang, Sebuah Interpretasi Kitab Wahyu. Surabaya: Momentum Christian Literatur, 2007.

[11] Ladd, George Eldon. A Commentary on the Revelation of John. Grand Rapids: William B. Eerdmans Publishing Company, 1972.

[12] Moulton, Harold K. Leksikon analitis Bahasa Yunani yang Direvisi, Diterjemahkan oleh Tandi Randa. .Jogyakarta: Randa's family Press, 2009.

[13] Mounce, Robert H. The Book of Revelation. Grand Rapids: William B. Eerdmans Publishing Company, 1977.

[14] Packer, J.I., Merill C. Tenney, William White, Jr., Ensiklopedi Fakta Alkitab, Bible Almanac 2. Malang: Gandum Mas, 2004

[15] Walvoord, John F. Pedoman lengkap Nubuat Alkitab. Bandung: Yayasan Kalam Hidup, 2003.

[16] The Revelation of Jesus Christ. Chicago: Moody Press, 1966. 